Original Research Article

\title{
Evaluation of the effect of piperine per se and its interaction with ondansetron on haloperidol induced catalepsy in Albino mice
}

\author{
Pooja Solanki Mishra, Sapna More*, Ashutosh Tiwari, Savita Vyas
}

Department of Pharmacology, MGM Medical College, Indore, Madhya Pradesh, India

Received: 16 February 2018

Accepted: 28 March 2018

\section{*Correspondence to:}

Dr. Sapna More,

Email: drsapnaindore@yahoo.in

Copyright: (C) the author(s), publisher and licensee Medip Academy. This is an openaccess article distributed under the terms of the Creative Commons Attribution NonCommercial License, which permits unrestricted noncommercial use, distribution, and reproduction in any medium, provided the original work is properly cited.

\begin{abstract}
Background: This study aims to evaluate the per se effect of piperine and its interaction with ondansetron on haloperidol induced catalepsy in swiss albino mice.

Methods: The piperine crystals were separated from crude extract of Piper nigrum. Catalepsy was induced by haloperidol $(1 \mathrm{mg} / \mathrm{kg}$, i.p.). Control group received $2 \%$ gum acacia $(10 \mathrm{ml} / \mathrm{kg})$, standard group ondansetron $(0.5 \mathrm{mg} / \mathrm{kg})$, test group piperine $(10 \mathrm{mg} / \mathrm{kg}$ ) and combination group ondansetron plus piperine $(0.5 \mathrm{mg} / \mathrm{kg}+10 \mathrm{mg} / \mathrm{kg})$, per oral, respectively. In acute study, drugs were administered only once, one hour prior to the haloperidol administration. Whereas in chronic study, catalepsy was determined on the seventh day of treatment.

Results: In acute study, from 60 min onwards after haloperidol administration, ondansetron and ondansetron plus piperine group resulted in significantly lower cataleptic scores than the control treated group. On the other hand, $120 \mathrm{~min}$ onwards ondansetron group showed significantly lower cataleptic scores (24.62) as compared to the ondansetron plus piperine group (31.50). In the chronic study, from 60 min onwards, ondansetron and the ondansetron plus piperine resulted in significantly lower cataleptic scores than the control treated group. Also the combination of ondansetron plus piperine was more significantly protective compared to ondansetron alone $(\mathrm{P}<0.05)$.

Conclusions: Piperine has the potential to be used as a bioenhancer when combined with other drugs which would reduce the dose of drugs and thereby adverse effects. It may act probably by enhancing the bioavailability as well as by inhibiting the metabolic pathways of other drugs.
\end{abstract}

Keywords: Bioenhancer, Catalepsy, Ondansetron, Piperine

\section{INTRODUCTION}

Schizophrenia is a mental disorder characterized by abnormal social behavior and failure to distinguish between real world and imaginary world. It is a chronic and severe disorder that affects person's thinking, feeling and behavior. Neuroleptics are commonly used to treat schizophrenia, but the major side effects of these drugs are extrapyramidal symptoms. ${ }^{1,2}$ The extrapyramidal symptoms are characterized by acute dyskinesias, dystonia, akinesia and akathisia. These effects such as akinesia, rigidity and tremors are called Parkinson's like syndrome, because in Parkinson's disease the major clinical symptoms include difficulty to move and change posture (akinesia and rigidity) and tremors. These effects of antipsychotic drugs are due to excessive blockade of dopamine D2 receptors and reduced dopaminergic transmission in extrapyramidal motor system. ${ }^{3}$ Therefore, phenothiazines (chloropromazine or haloperidol) are commonly used to produce Parkinson's like extrapyramidal symptoms in laboratory animals and to study antiparkinson drugs. The central serotonergic system modulates nigrostriatal dopaminergic transmission. 5- $\mathrm{HT}_{3}$ 
antagonists are reported to diminish neuroleptic-induced catalepsy. ${ }^{4}$ Hence ondansetron, a $5-\mathrm{HT}_{3}$ antagonist was used as standard drug in this study to compare the anticataleptic effect of the test compound, piperine.

Piperine, the chief constituent of piper nigrum, commonly known as black pepper is the oldest and best-known spices in the world. Belonging to the Piperaceae family, which is cultivated in the damp nutrient rich soil of South India, it is also found in Indonesia, Malaysia, and Brazil. ${ }^{5}$ In India, it is called "kali mirch", which is a common household spice.

The chief constituents of piper nigrum are crystalline alkaloid piperine (5-8.25\%), volatile oils (1-2.3\%) and a resin called Chavicin. ${ }^{6}$ Studies have shown that piperine increases the absorption of certain essential elements such as selenium, vitamin B and beta-carotene. ${ }^{7}$ Also there are animal and human studies demonstrating that piperine can significantly increase the bioavailability of numerous drugs and some nutritional supplements. This effect has been studied with some antimicrobial, antiprotozoal, antihelmintic, antihistaminic, non-steroidal antiinflammatory, muscle relaxant and anticancer drugs. ${ }^{8}$ In view of these facts, the present study was undertaken to evaluate the per se effect of piperine and its interaction with ondansetron on haloperidol induced catalepsy in swiss albino mice.

\section{METHODS}

\section{Isolation of Piperine ${ }^{9}$}

Piper nigrum crude extract was obtained from Amsar Pvt. Ltd., Indore (M. P.), which contained about 95\% of piperine. The extract was dissolved in $5 \mathrm{ml}$ of ethyl alcohol and $10 \mathrm{ml}$ of $10 \% \mathrm{w} / \mathrm{v}$ of alcoholic potassium hydroxide added with constant stirring. It was then filtered and allowed to stand overnight. The yellow needle-shaped crystals of piperine were separated next day.

The purity of the isolated piperine was verified by checking its melting point $\left(128-131^{\circ} \mathrm{C}\right)$, treating it with concentrated sulphuric acid (blood red color obtained), by thin layer chromatography (single spot obtained) and ultraviolet spectrophotometer (absorption maxima at 343 $\mathrm{nm}$ for piperine). ${ }^{10,11}$

\section{Experimental animals}

Swiss albino mice of either sex weighing between 25 $35 \mathrm{gm}$, were procured from the central animal house, M.G.M. Medical College, Indore and acclimatized for a period of 7 days at room temperature $\left(25 \pm 2^{\circ} \mathrm{C}\right)$ and $50 \pm 15 \%$ relative humidity. They were housed in standard cages and maintained on standard laboratory diet and water $a b$ libitum. The study was carried out in the Department of Pharmacology, M.G.M. Medical College, Indore (M.P.), India. The study protocol was approved by the Institutional Animal Ethics Committee (IAEC).

\section{Drugs and groups}

Ondansetron $1 \mathrm{mg} / \mathrm{kg}$ and piperine $10 \mathrm{mg} / \mathrm{kg}$ were prepared in $2 \%$ gum acacia (vehicle) and administered per oral (p.o.) with the help of oral gavage. Haloperidol $1 \mathrm{mg} / \mathrm{kg}$ was dissolved in distilled water and given intraperitoneally. ${ }^{4,12}$

Group I received $2 \%$ gum acacia $10 \mathrm{ml} / \mathrm{kg}$, Group II received ondansetron $(0.5 \mathrm{mg} / \mathrm{kg})$, Group III received piperine $(10 \mathrm{mg} / \mathrm{kg})$ and Group IV received ondansetron and piperine $(0.5 \mathrm{mg} / \mathrm{kg}+10 \mathrm{mg} / \mathrm{kg})$.

\section{Experimental design}

Catalepsy was induced by haloperidol $(1 \mathrm{mg} / \mathrm{kg}$, i.p.) and assessed at $30 \mathrm{~min}$ interval until at the end of $240 \mathrm{~min}$. Catalepsy was assessed in terms of the time for which the mouse maintained an imposed position with both front limbs extended and resting on a $4 \mathrm{~cm}$ high wooden bar. The end point of catalepsy was considered to occur when both front paws were removed from the bar or if the animal moved its head in exploratory manner. A cut off time of 1100 seconds was applied. ${ }^{13}$

\section{Scoring method}

If the animal maintained the imposed posture for at least 20 seconds, it was considered to be cataleptic and given one point. For every additional 20 seconds that the cataleptic posture was maintained, one extra point was given.

In acute study, ondansetron, piperine and their combination were administered only once, one hour prior to the haloperidol administration.

In chronic study, these drugs were administered once daily for seven days. Catalepsy was determined one hour after haloperidol administration on the seventh day of treatment.

\section{Statistical analysis}

Results were analyzed by SPSS Version 21. For each group, mean \pm SEM was calculated, and the data was analyzed by one way ANOVA followed by multiple Tukey's post hoc comparison test for both acute and chronic study. $\mathrm{P}<0.05$ was considered to be statistically significant value.

\section{RESULTS}

\section{Acute study}

In acute study, administration of the standard and the test drug gave cataleptic scores similar to that of the control treated group. However, from $60 \mathrm{~min}$ onwards after haloperidol administration, ondansetron and combination group resulted in significantly lower cataleptic scores than the control treated group. 
On the other hand, 120 min onwards ondansetron group showed significantly lower cataleptic scores (24.62) as compared to the combination of ondansetron plus piperine (31.50) (Table 1).

Table 1: Effect of acute administration of ondansetron, piperine and their combination on haloperidol induced catalepsy.

\begin{tabular}{|lllllll|}
\hline Treatment & Dose, $\mathrm{mg} / \mathrm{kg}$ orally & \multicolumn{4}{l|}{ Time after haloperidol $(\mathbf{m i n})$} & \\
& & $\mathbf{3 0}$ & $\mathbf{6 0}$ & $\mathbf{9 0}$ & $\mathbf{1 2 0}$ & $\mathbf{2 4 0}$ \\
\hline Control & $10 \mathrm{ml} / \mathrm{kg}$ & $13.25 \pm 1.06$ & $24.87 \pm 1.14$ & $33.25 \pm 1.43$ & $46 \pm 1.31$ & $51.62 \pm 1.13$ \\
\hline Ondansetron & 0.5 & $10.37 \pm 0.86$ & $14.50 \pm 1.36^{*}$ & $22 \pm 1.54^{*}$ & $24.62 \pm 1.55^{*}$ & $32.62 \pm 1.51^{*}$ \\
\hline Piperine & 10 & $14.75 \pm 0.92$ & $30.25 \pm 1.65$ & $40.51 \pm 1.26$ & $55 \pm 1.26$ & $61 \pm 2.30$ \\
\hline Ondansetron+Piperine & $0.5+10$ & $12.37 \pm 1.45$ & $16.51 \pm 0.98^{*}$ & $23.62 \pm 1.42^{*}$ & $31.50 \pm 2.07^{*+}$ & $40.87 \pm 1.02^{* \dagger}$ \\
\hline One-way & $\mathrm{F}$ & 2.76 & 31.45 & 37.11 & 75.42 & 60.70 \\
ANOVA & $\mathrm{P}$ & $>0.05$ & $<0.001$ & $<0.001$ & $<0.001$ & $<0.001$ \\
\hline
\end{tabular}

One way ANOVA followed by multiple Tukey's comparison test. Values are mean $\pm \mathrm{SEM}, \mathrm{df}=3,28, * \mathrm{P}<0.05$, compared to control group, $\dagger \mathrm{P}<0.005$, compared to standard (ondansetron) group

Table 2: Effect of chronic administration of ondansetron, piperine and their combination on haloperidol induced catalepsy.

\begin{tabular}{|c|c|c|c|c|c|c|}
\hline \multirow[t]{2}{*}{ Treatment } & \multirow[t]{2}{*}{ Dose, mg/kg orally } & \multicolumn{5}{|c|}{ Time after haloperidol (min) } \\
\hline & & 30 & 60 & 90 & 120 & 240 \\
\hline Control & $10 \mathrm{ml} / \mathrm{kg}$ & $13.12 \pm 1.83$ & $19.62 \pm 1.08$ & $24.87 \pm 1.11$ & $33.25 \pm 1.09$ & $37 \pm 1.72$ \\
\hline Ondansetron & 0.5 & $11.87 \pm 0.95$ & $14.87 \pm 0.83^{*}$ & $19.37 \pm 0.81^{*}$ & $23.25 \pm 0.92^{*}$ & $20.50 \pm 1.06^{*}$ \\
\hline Piperine & 10 & $12.62 \pm 0.84$ & $24.75 \pm 1.12$ & $33.12 \pm 1.58$ & $39 \pm 1.80$ & $46.75 \pm 1.66$ \\
\hline Ondansetron+Piperine & $0.5+10$ & $10.12 \pm 1.05$ & $12.51 \pm 1.22^{*}$ & $15.87 \pm 0.91^{*}$ & $14.12 \pm 0.87^{* \dagger}$ & $10.50 \pm 1.47^{* \dagger}$ \\
\hline One-way & $\mathrm{F}$ & 2 & 25.30 & 43.28 & 79.57 & 116.69 \\
\hline ANOVA & $\mathrm{P}$ & $>0.05$ & $<0.001$ & $<0.001$ & $<0.001$ & $<0.001$ \\
\hline
\end{tabular}

One way ANOVA followed by multiple Tukey's comparison test. Values are mean $\pm \mathrm{SEM}$, $\mathrm{df}=3,28, * \mathrm{P}<0.05$, compared to control group, $\uparrow \mathrm{P}<0.05$, compared to standard (ondansetron) group

\section{Chronic study}

In the chronic study, administration of the standard drug and the test compound $30 \mathrm{~min}$ after the haloperidol dose on the seventh day, gave the cataleptic score similar to that of the control treated group. However, from $60 \mathrm{~min}$ onwards after haloperidol administration, standard and the combination of standard plus piperine resulted in significantly lower cataleptic scores than the control treated group. Unlike the acute study, the result of the chronic study showed that the combination of standard plus piperine is more significantly protective against ondansetron alone $(\mathrm{P}<0.05)$ (Table 2$)$.

\section{DISCUSSION}

Typical neuroleptic agents such as chlorpromazine, haloperidol and reserpine induced catalepsy in rodents is most commonly used model to test the extrapyramidal side effects of antipsychotic agents and to evaluate antiparkinson drugs. ${ }^{14}$ In the present study we observed the effect of piperine per se and its interaction with ondansetron on haloperidol induced catalepsy in swiss albino mice.
In acute as well as chronic study piperine increases the cataleptic score of haloperidol that might be due to enhanced activity of haloperidol. Here haloperidol was used in parenteral form, hence it may be considered that beside absorption some other mechanisms might also be involved in enhancing the bioavailability of drugs. Chen J et al, suggested that piperine inhibit the enzyme involved in N-dealkylation reaction. ${ }^{15}$ Haloperidol is also metabolized by $\mathrm{N}$-dealkylation, hence it might be the inhibition of metabolism of haloperidol responsible for increased efficacy. Not only the effect of haloperidol was increased but the effect of ondansetron to control the activity of haloperidol was also reduced. This observation remains restricted to the acute effect only. With chronic administration of piperine the cataleptic score of haloperidol was increased but the ability of ondansetron to reverse the cataleptic effect was not inhibited. It may be perhaps due to increase bioavailability of ondansetron that dominates over the increased efficacy of haloperidol, when piperine was used for a long period.

Both the experiments suggest that piperine has bioenhancing property similar to other studies suggesting its similar action. The probable mechanisms are, by 
promoting rapid absorption and by increasing the solubility of the drugs. ${ }^{16}$ It enhances the gastrointestinal blood flow as shown by a study done by Annamalai AR et al, and stimulates Gamma-glutamyl transpeptidase activity, thereby increasing the uptake of drugs by gastrointestinal epithelium. ${ }^{6,17}$

Another very important mechanism of action of bioenhancement is by inhibition of drug metabolism by piperine. ${ }^{18}$ Piperine has been shown to inhibit different cytochrome P450 isoforms as well as UDP-glucuronyl transferase and other phase II reactions, thus decreasing the metabolism of other drugs. ${ }^{19}$

Thus, piperine has the potential to be used as a bioenhancer when combined with other drugs which would reduce the dose of drugs and thereby possibly reduce their adverse effects.

\section{CONCLUSION}

From the present study, we concluded that piperine has a bioenhaning effect when given chronically. Bioenhancing effect suggests that judicious use of piperine in proper doses at proper timing may work to reduce the required dose of drugs, toxicity and thereby cost of the therapy. At the same time, it may enhance the efficacy of drug as well as may hasten the onset of action. The bioenhancing effects if properly explored may prove as a boon for patients in need of safe medicines. Further studies are needed to explore such combinations.

\section{ACKNOWLEDGEMENTS}

The authors are grateful to Mr. N. Peter, Amsar Pvt. Ltd., Indore. Authors would also like to acknowledge Dr. R.P. Agrawal, Ex-Professor and Head, Department of Pharmacology, M.G.M. Medical College, Indore, (M.P.) for his guidance and support in carrying out the work.

Funding: No funding sources

Conflict of interest: None declared

Ethical approval: The study was approved by the Institutional Animal Ethics Committee

\section{REFERENCES}

1. Casey DE. Tardive dyskinesia: Pathophysiology and animal models. J Clin Psychiat. 2000;61:5-9.

2. Kulkarni SK, Naidu PS. Tardive dyskinesia: an update. Drugs Today. 2001 Feb 1;37(2):97-119.

3. Somani RS, Kasture VS, Kasture SB. Haloperidol inhibits (-) bicucullin induced seizures and bicucullin potentiates haloperidol induced catalepsy in mice. Indian J Pharmacol. 1999;31:434-6.

4. Silva SR, Futuro-Neto HA, Pires JG. Effects of 5-HT3 receptor antagonists on neuroleptic induced catalepsy in mice. Neuropharmacology. 1995 Jan 1;34(1):97-9.
5. Cochran, Tim. Piperine Cochran Foundation of Medical Research. Revised January 30, 1998. Available at: http://www.cochranfoundation.com /reports/piperin.htm. (4-1-00)

6. Johri RK, Zutshi U. An Ayurvedic formulation Trikatu and its constituents. J Ethnopharmacol. 1992;37:8591.

7. Badmaev V, Majeed M, Norkus EP. Piperine, an alkaloid derived from black pepper increases serum response of beta-carotene during 14-days of oral betacarotene supplementation. Nutr Res. 1999;19:381-8.

8. Park IK, Lee SG, Shin SC, Park JD, Ahn YJ. Larvicidal activity of isobutylamides identified in Piper nigrum fruits against three mosquito species. J Agric Food Chem. 2002;50(7):1866-70.

9. Kokate CK, Textbook of practical pharmacognosy, 4th edn., p 143, Vallabh Prakashan, New Delhi 2003.

10. Harry Lawless. Oral chemical irritation: psychophysical properties. Chem Senses. 1984;9:14355.

11. Merck Index. An encyclopedia of chemicals, drugs and biologicals. $12^{\text {th }}$ Edn., Merck and Co., Whitehouse Station, NJ; 1996:1286.

12. Pemminati S, Nair V, Dorababu P, Gopalakrishna HN, Pai MRSM. Effect of ethanolic leaf extract of Ocimum Sanctum on haloperidol induced catalepsy in albino mice. Indian J Pharmacol. 2007;39(2):87-9.

13. Ferre S, Guix T, Prat G, Jane F, Casas M. Is experimental catalepsy properly measured? Pharmac Biochem Behav. 1990;35:753-7.

14. Dandiya PC, Bhargava, LP. Arch. Int. Pharmacodyn. Therap. 1968;176:157-67.

15. Chen J, Raymond K. The role of CYP3A4 and pglycoprotein in food-drug and herb-drug interactions. Pharmacist. 2006;25(9):732-8.

16. Lee KW, Everts H, Beynen AC. Essential oils in broiler nutrition. Int J Poult Sci. 2004;3:738-52.

17. Annamalai AR, Madhavan R. Effects of trikatu and its individual components and piperine on the gastrointestinal tract. Trikatu: a bioavailability enhancer. Indian Drugs. 1989;27:595-604.

18. Johri RK, Thusu N, Khajuria A, Zutshi U. Piperinemediated changes in the permeability of intestinal epithelial cells. Biochemical Pharmacol. 1992;43:1401-7.

19. Fujiwara Y, Naithou K, Miyazaki T, Hashimoto K, Mori K, Yamamoto Y. Two new alkaloids, pipercyclobutanamides $\mathrm{A}$ and $\mathrm{B}$, from Piper nigrum. Tetrahedron Letters. 2001 Mar 26;42(13):2497-9.

Cite this article as: Mishra PS, More S, Tiwari A, Vyas S. Evaluation of the effect of piperine per se and its interaction with ondansetron on haloperidol induced catalepsy in Albino mice. Int J Basic Clin Pharmacol 2018;7:1119-22. 